\title{
An Unusual Parasite in a Colostomy Wound
}

\author{
Selvaraj Stephen ${ }^{1}$, Robinson Smiles ${ }^{2}$
}

\begin{abstract}
Hookworms are common intestinal nematodes in tropical countries. Two of them are, viz., Ancylostoma duodenale and Necator americanus. Small intestine of man is the normal habitat of adult hookworms. Both the adult worms and eggs are excreted and can be seen in the stool specimens. The presence of adult $A$. duodenale and the eggs in the colostomy wound of a male patient makes an interesting case report to share with the medical fraternity.

Keywords: Ancylostoma duodenale, Colostomy wound, Hookworm.

Journal of Gastrointestinal Infections (2019): 10.5005/jp-journals-10068-3028
\end{abstract}

\section{Case Description}

A 43-year-old male patient was admitted in the general surgery ward of our tertiary care teaching hospital for colostomy. On the third postoperative day, the patient had an uneasy feeling around the colostomy wound site. While cleaning the wound with a gauze cloth, he found that some tissue bits were coming out. The surgeon wondered whether this could be a case of "flesh-eating bacteria" and sent the gauze with the tissue debris to microbiology laboratory.

\section{LABORATORY INVESTIGATIONS}

In the microbiology laboratory, the tissue material was transferred to a Petri dish and washed with sterile distilled water. Then to our surprise, few thread-like worms wriggled out and were in three pairs. The morphology of these adult male and female nematodes "in copula" appearing as the alphabet " $Y$ " fits the textbook description of the hookworm, A. duodenale, macroscopically (Fig. 1) and under a scanner lens ( $4 \times$; Fig. 2 ) which has been reported from Puducherry. ${ }^{1,2}$ Saline wet mount with cover slip observed under $10 \times$ objective showed few nonbile-stained oval eggs with blastomeres, which are typical of hookworm eggs.

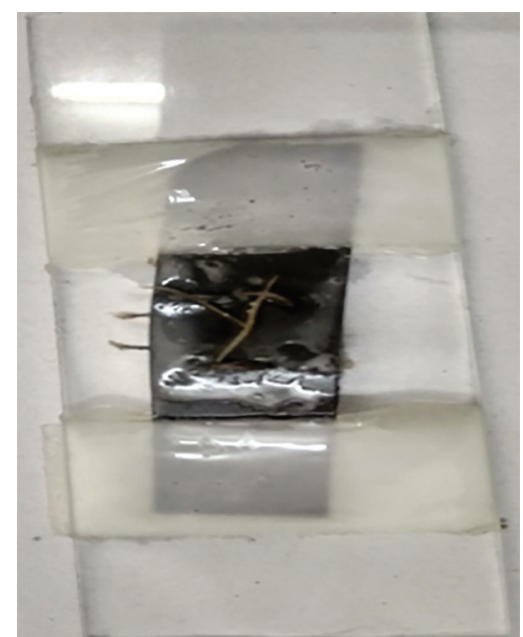

Fig. 1: Adult male and female hookworms "in copula"—actual size
${ }^{1}$ Department of Microbiology, Mahatma Gandhi Medical College and Research Institute, Sri Balaji Vidyapeeth Deemed University, Puducherry, India

${ }^{2}$ Department of General Surgery, Mahatma Gandhi Medical College and Research Institute, Sri Balaji Vidyapeeth Deemed University, Puducherry, India

Corresponding Author: Selvaraj Stephen, Department of Microbiology, Mahatma Gandhi Medical College and Research Institute, Sri Balaji Vidyapeeth Deemed University, Puducherry, India, Phone: +91 9894383368, e-mail: Stephens4950@gmail.com

How to cite this article: Stephen S, Smiles R. An Unusual Parasite in a Colostomy Wound. J Gastrointest Infect 2019;9(1):53-54.

Source of support: Nil

Conflict of interest: None

\section{Discussion}

Hookworm infection is worldwide in distribution. The two different hookworms are $A$. duodenale and $N$. americanus. The habitat of adult hookworms is the small intestine of humans. While 1,200 million people are infected by this nematode globally, about 20 million Indian population are affected. An adult female worm lays 25,000 to 35,000 eggs per day. Although most of the cases are asymptomatic

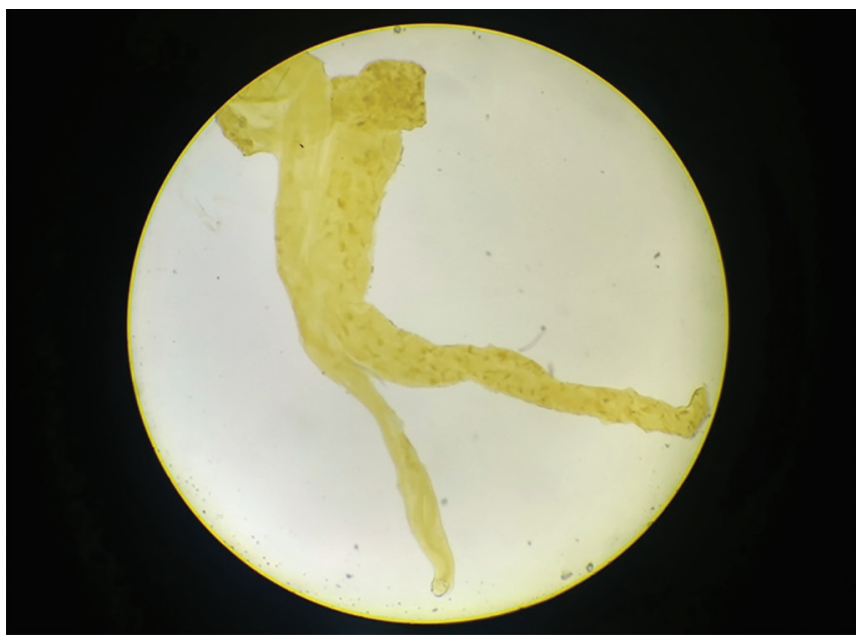

Fig. 2: Male and female hookworms—under scanner lens (4X)

(-) The Author(s). 2019 Open Access This article is distributed under the terms of the Creative Commons Attribution 4.0International License (https://creativecommons. org/licenses/by-nc/4.0/), which permits unrestricted use, distribution, and non-commercial reproduction in any medium, provided you give appropriate credit to the original author(s) and the source, provide a link to the Creative Commons license, and indicate if changes were made. The Creative Commons Public Domain Dedication waiver (http://creativecommons.org/publicdomain/zero/1.0/) applies to the data made available in this article, unless otherwise stated. 
in heavy worm load, it can lead to microcytic hypochromic anemia, requiring treatment with iron supplement. The patient was given mebendazole $100 \mathrm{mg}$ twice daily for 3 days and was discharged.

The inquisitiveness of the patient, the clinical interest of the surgeon, and a simple laboratory investigation helped in solving this interesting puzzle.

\section{References}

1. Parija SC. Textbook of Medical Parasitology. 2nd ed., Chennai, New Delhi: All India Publishers \& Distributors, pp. 301-308.

2. Parija SC, Malini G, Rao RS. Prevalence of human hookworm species in Pondicherry, India. Trop Geogr Med 1992;44(4): 378-381. 